\title{
Rail-Road Hinterland Intermodal Terminal Location in West Africa Region-Case Study of Corridor Port of Abidjan to Ouagadougou-Bamako
}

\author{
Brou Mathias Allate \\ School of Economics and Management, Shanghai Maritime University, Shanghai, China \\ Email: abromat@yahoo.fr
}

How to cite this paper: Allate, B.M. (2019) Rail-Road Hinterland Intermodal Terminal Location in West Africa Region-Case Study of Corridor Port of Abidjan to Ouagadougou-Bamako. Open Journal of Applied Sciences, 9, 246-259.

https://doi.org/10.4236/ojapps.2019.94021

Received: April 4, 2019

Accepted: April 23, 2019

Published: April 26, 2019

Copyright () 2019 by author(s) and Scientific Research Publishing Inc. This work is licensed under the Creative Commons Attribution International License (CC BY 4.0). http://creativecommons.org/licenses/by/4.0/

\begin{abstract}
Efficient and effective movement of goods is very critical in today's competitive environment especially for developing countries suffering from crippling logistics costs which limit their competitive ability in the global economy. Putting in place an optimal logistics network design offers great potential for logistics cost reduction and service quality improvement [1]. Therefore, this paper presents a model for effective integration of inland intermodal terminal into logistics network. The model simultaneously determines the number and location of inland terminals in network that minimize the total cost of freight flow to hinterland. The model uses Abidjan port in Cote d'Ivoire as the case study for solving numeric examples. The problem will be formulated in the case of a rail-road network where post-routing is done by road and rail link between terminal. We present a linear optimization model which is implemented using LINGO Mathematical Modeling Language.
\end{abstract}

\section{Keywords}

Intermodal Terminals, Localization, Port Hinterland, Corridor, Port of Abidjan

\section{Introduction}

The business environment in which ports, ocean carriers and logistics service providers are acting is changing rapidly due to changing economic conditions, competition and technology. During the last decade container trade experienced phenomenal growth in term of container volumes and ship size (Figure 1). Increase in container volume causes increased pressure on entire logistics network resulting into port congestion, high dwell time and higher logistics costs [2]. 


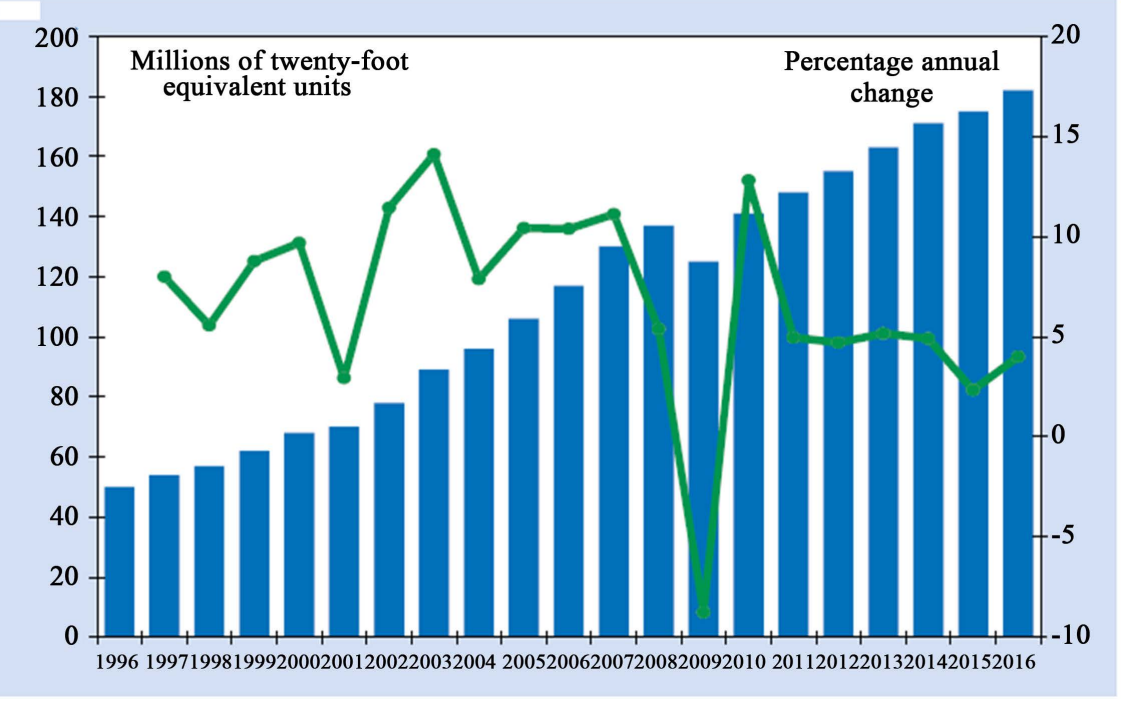

Figure 1. Global Container Trade 1996-2016 (TEUs). Source: United Nation Conference on Trade and Development, UNCTAD, 2016.

Ports are particularly affected by ever increasing container volumes as their operational capability becomes highly constrained. As acknowledged [3] lack of sufficient container storage space is one the critical challenges facing ports today. Consequently, consistent lack of capacity may cause port customers to shift to competition ports. Traffic volume growth entails a mismatch between port resources (i.e. yard capacity, handling facilities and gate capacity) and ability to handle those volumes. This situation leads to congestion as port user end up interfering with each other in the utilization of port resource [4].

The freight transportation network has experienced an evolution of terminals which connect seaport with their hinterlands. Several names apply to these terminals including inland Container Depots (ICDs), Dry Port, Container Freight Stations (CFS), inland intermodal terminals, interior port (interports), etc.

Dry ports are mature and well established in developed countries and are increasingly embraced in developing economies. The dry port concept is based on a seaport directly connected with inland intermodal terminals where goods in intermodal loading units can be turned in as if directly to the seaport.

Extensive dry ports and Inter modal freight Terminal related studies have been carried out with focus on developed economics but less has been done with respect to developing economies despite their increasing role in the global supply chain. Major works by [5], [6], [7] and [8] to mention but a few concentrated on Europe and North America. However, in the past few years considerable research works have turned attention to developing countries. Notably the works of [9], [10], $\mathrm{Ng}$ and [8], [11], [12] and [13] have extensively examined the intermodal terminal phenomenon in Asia with India dominating these studies. [13] turned their attention on Brazil, research on evolution and integration of inland container terminal in logistics systems covering developing countries and West Africa in particular is still limited and needs to be explored further. 
Implementation of inland terminal unleashes a set of new challenges upon container transport industry. Challenges include affective determination of location and number of terminal to insert in the logistics network as well as the ultimate routing of freight to final destination that minimizes the transportation cost born by shippers and the economy at large. In recognition of the competitive environment in which ports operate; trade-offs between cost adding and cost saving properties of inland terminal needs to be given due consideration when integration of inland freight terminal into freight network.

Therefore this paper presents a model for effective integration of inland intermodal terminal into logistics network. The model simultaneously determines the number and location of inland terminals in network and optimal freight routing to the hinterlands that minimize the total cost of flow. The model uses Abidjan port in Cote d'Ivoire as the case study for solving numeric examples.

\section{Freight Flow Modelling and Mathematic Formulation}

\subsection{Freight Flow Modelling}

In this thesis, intermodal terminal location problem involves determination of number of terminal in such way that customer demand are met at minimum shipping cost. In this regard the problem is addressed as a network flow problem in logistic network with not direct shipping constraint as depicted in Figure 2 below.

The goal is to locate terminals and assign demand nodes to the appropriate terminals.

A simply layout of intermodal terminal insertion is show in Figure 2. The figure depicts the configuration of the network including one seaport representing Abidjan which make our case study in this research work. Sea port is freight generation nodes for the flow in inland destination. Apart from the seaport the network includes inland nodes which serves as final destination point for import freight.
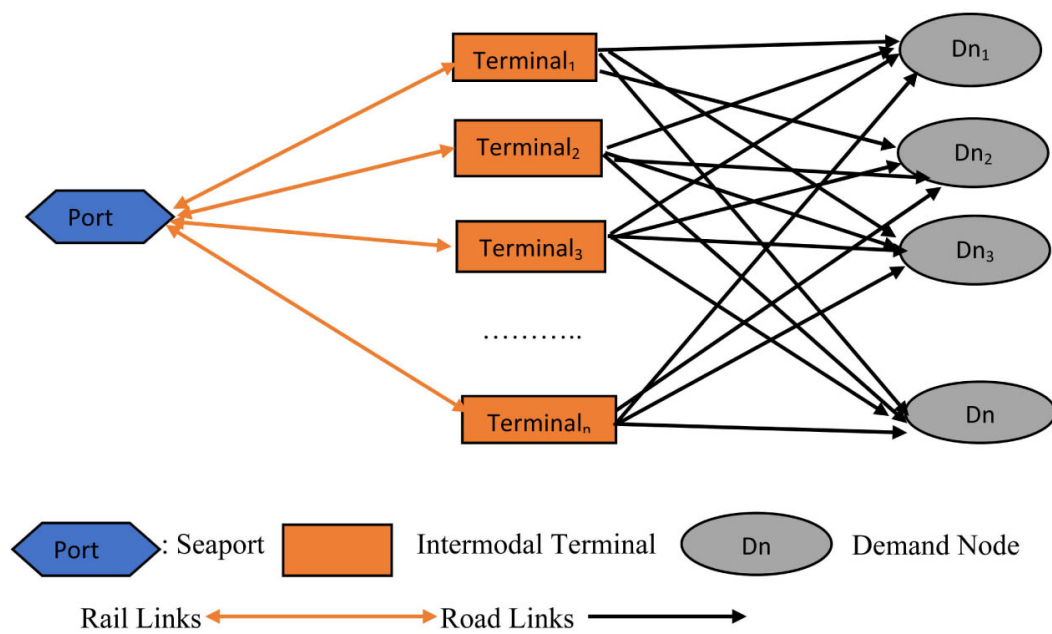

Figure 2. Intermodal terminal integration in transportation network. Source: Author. 


\subsection{Model Formulation}

The problem will be formulated in the case of a rail-road network where postrouting is done by road and rail link between terminal.

We present a linear optimization model which is implemented using LINGO Mathematical Modeling Language. The model simultaneously determines the optimal number of terminal to include in the network that result into the minimum container shipping costs to final destination. The model uses Abidjan port, Cote d'Ivoire as a case study for demonstration of a numerical examples.

Here are the different variables used in the model:

Model Parameters:

$O$ : set of freight origin (Abidjan port)

I: set of terminals

J: set of demand nodes

$m$ : Number of demand nodes

$n$ : Number of potential terminals indexed by $j, j \in J=\{1, \cdots, n\}$

$M$ : constant equal to total quantity (Ton) of freight to be shipped from port to hinterland

$p$ : Number of terminal to be located, $1 \leq p \leq n$

$c_{o i}$ : The unit transportation cost from port to terminal I (rail link) in Ton/Kilometer

$c_{i j}$ : The unit transport cost from terminal to final demand node in Ton $/ \mathrm{Km}$ (road link)

$d_{o i}:$ Railway distance from origin to terminal

$d_{i j}$ : Road distance from terminal to final demand node

$r_{o i}:$ Rail mode transport

$r_{i o}$ : Road mode Transport

$F_{i}$ : Fixed terminal installation cost at terminal $i$.

$a_{j}:$ Demand at node $j$

Decision Variables: Location variable

$y_{i}=1$ if terminal is located at potential terminal $i$

0 otherwise

Minimize $Z$ :

$$
\min =\sum_{o} \sum_{i} \sum_{j} a_{o i} c_{o i} d_{o i} r_{o i}+\sum_{o} \sum_{i} \sum_{r} a_{i j} c_{i j} d_{i j r} r_{i j}+\sum \sum F_{i}
$$

Subjects to:

$$
\begin{gathered}
\sum_{i \in I} y_{i}=P \\
\sum_{j \in J} y_{i j}=1 \\
y_{j i}-a_{i} \leq 0 \\
\sum_{i} \sum_{j} a_{j}=M \\
a_{o i} \geq 0 ; a_{i j} \geq 0
\end{gathered}
$$




$$
y_{i}=\{0 ; 1\}
$$

\subsection{Constraints Description}

The objective function (1) minimizes the total cost of moving freight import from the port to final destination, being the sum of cost from port to terminal, transportation cost from terminal to hinterland and terminal implementation cost.

The constraint (2) states that P terminals must be located. The constraint (3) requires that each demand node $j$ be assigned to exactly one terminal $i$. Constraints (4) limit the assignment of demand nodes to open terminal. The constraint (5) ensure that the sum of goods routed via terminal is equal to the demand associated with each origin/ destination pair.

The constrain (6) defines nonnegative parameter. And the (7) is the standard integrity constraints.

\section{The Case of Abidjan Port Hinterland, Cote d'Ivoire}

\subsection{Abidjan Port Hinterland}

The hinterland of a port is basically made up of areas where the port serves and can be served from. To wit, a hinterland is the area over which a port extracts its main clientele base. Port hinterlands can basically be categorized into Captive hinterlands and Contestable hinterlands the captive hinterlands are areas where the port is able to reach and serve its customers and clients at a very competitive price. It can also be described as areas where the port has a well-established clientele base and does not face any form of rivalry from neighboring ports. Because of a lower generalized transportation cost, some ports enjoy a considerable amount of competitive advantage over other ports and so in areas where a port enjoys such competitive advantage, such areas or regions can be referred as its captive hinterlands. So consequently, an immense amount of cargoes to/from this region are handled by the port, which considers those areas as its captive hinterlands. In the specific case of the Abidjan port in Cote d'Ivoire, the four-walls of Cote d'Ivoire could be described as its captive hinterlands because those are the areas that do not receive any competition from any neighboring ports such as Tema, Lome and Cotonou.

Contestable hinterland where no port has a continual cost advantage over other neighboring ports, port competition becomes fiercest, and these areas can be referred to as Contestable hinterlands. To wit, the contestable hinterlands of a port are those areas that the port serves and can be served from but are also up for competition from other ports. Depending on the efficiency of a port, it can lose or maintain or even expand its contestable hinterlands. Taking the West Africa region countries under consideration in this study, their contestable hinterlands are the Sahel regions of West, Africa. These are regions, which are basically land-locked and need the services of these ports to serve as a gateway for maritime transport (Niger, Burkina Faso and Mali) (Figure 3). 


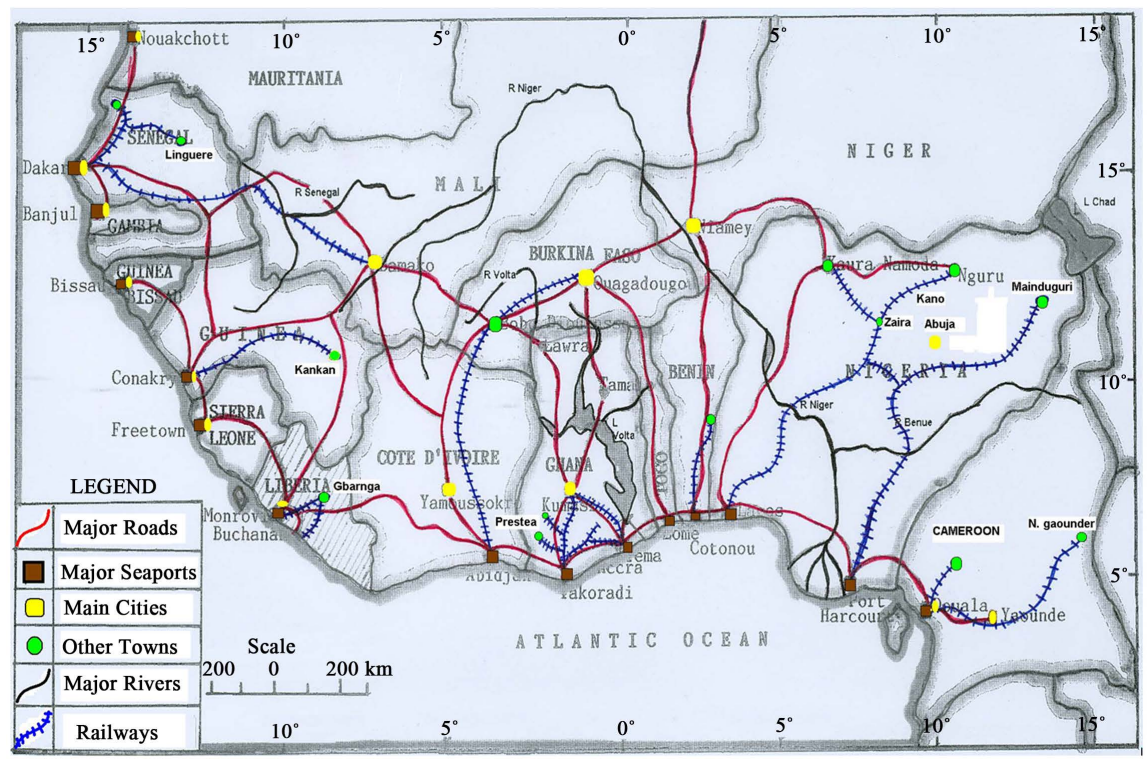

Figure 3. West Africa map showing Abidjan Port Hinterland and the Corridor Abidjan to Ouagadougou-Bamako. Source: Source: Adorkor J. K. (1993).

\subsection{Abidjan Ouagadougou and Abidjan Bamako Corridors}

Corridors Abidjan-Ouagadougou and Abidjan-Bamako overlaps partially, connecting Ivory Coast in Burkina Faso to a lesser extent in Niger and in Mali. The corridor Abidjan-Ouagadougou is at the same time a railroad. The corridor Abidjan-Bamako follows the same road of Abidjan to Ouangolodougou, then branches out to Bamako, whereas the road/railroad borrows the railroad connecting Abidjan with Ferkéssédougou and continues by the road to Bamako.

\subsection{Potential Terminal Location Site}

The goal is to describe a method that helps determine the best potential locations. The basic idea is to use commodity flows and their geographic dispersion as input to determine a set of potential locations for rail-road container terminals

Terminal localization problems require a set of potential locations, as well as the matrices of flows and costs between these locations. In the case of a large network, the number of potential locations becomes too large for this location problem to be resolved by an exact method. The methodology used to determine the potential locations in our case study will be one of the approaches presented by [14]: potential locations are nodes connected to railways and roads (Table 1).

The main cities on railway link are considered as potential sites for the terminals.

When these potential locations are determined, the possible container flows between them are evaluated by taking into account the demands related to the market areas. Then, transportation costs between these potential locations are evaluated by multiplying the distances obtained by the unit cost, road or rail depending on the mode of transport envisaged. 
Table 1. Potential intermodal terminal.

\begin{tabular}{ccc}
\hline Potential Terminal ID & City Name as Potential Terminal & $\begin{array}{c}\text { Distance from Port of Abidjan } \\
\text { by Railway (Kilometer) }\end{array}$ \\
\hline Y1 & Abgoville & 83 \\
Y2 & Dimbokro & 180 \\
Y3 & Bouake & 315 \\
Y4 & Katiola & 371 \\
Y5 & Ferkessedougou & 558 \\
Y6 & Ouangolodougou & 606 \\
\hline
\end{tabular}

\subsection{Demand Nodes and Quantity Demanded}

Spatial aggregation of demand nodes is a very common technique used to solve location problems. It was like reducing the size of these problems to make their solution possible. The aggregation of the nodes of demand is frequently made by a technique of classification. The classification makes it possible to group data (in the problem which concerns us: demand nodes) in several classes so that the data of the same class are as similar as possible and that the classes are as different as possible. Then each class is represented by a single demand node, usually the centroid of the class.

Indeed port statistics only indicate final destination of freight in the country without any indication of the region, district, city or town. Due to this deficient, we adopted approach base on population and Gross Domestic Production correlation to determine the quantity on freight (tons) at each demand point.

Demand nodes in Abidjan port hinterland in Cote d'Ivoire were established based on economic and demographic factors. It was assumed that the demand for freight was directly correlated to population of given region and their purchasing power measured in term of GDP per capita. Since socio-economic factor such as per-capita income and population are useful in determining freight production and attraction [15]. The same were used in determining freight destination in Ivorian market. Cote d'Ivoire is subdivided into 12 administrative region and 2 autonomous districts (Table 2). These region and districts were used to define the consumption market for freight imports. The capital of each region is designated as the final cargo center used for analysis in this study.

For the transit countries of Mali, Burkina Faso and Niger the capital city of each country was designated as the cargo center for that country as follows Bamako (Mali), Ouagadougou (Burkina Faso), and Niamey (Niger).

Now, the flow matrices and costs between each pair of potential locations are estimated and can serve as inputs to terminal location problem.

\subsection{Estimation of the Potential Terminal Market Areas}

The problem of market areas has been addressed by many authors, for example Hotelling H. (1929) [16] or Berry B. J. L. (1967) [17], Niérat (1997) [18] studied 
Table 2. Freight distribution quantities and demand node by district, region or country.

\begin{tabular}{cccc}
\hline District/Region/Countries & $\begin{array}{c}\text { Capital as } \\
\text { Cargo Center }\end{array}$ & $\begin{array}{c}\text { Demanded Quantities } \\
\text { at each Node (Tons) }\end{array}$ & $\begin{array}{c}\text { Distance between } \\
\text { Port \& Nodes (Km) }\end{array}$ \\
\hline Abidjan & Abidjan City & $2,386,171$ & - \\
Yamoussoukro & Yamoussokro & 180,239 & 236 \\
Lacs & Dimbokro & 637,983 & 180 \\
Comoe & Abengourou & 609,823 & 209 \\
Denguele & Odienne & 146,888 & 717 \\
Goh Djiboua & Gagnoa & 813,715 & 272 \\
Lagunes & Dabou & 749,218 & 46 \\
Montagnes & Man & $1,202,320$ & 585 \\
Sassandra Marahoue & Daloa & $1,162,470$ & 373 \\
Bas Sassandra & San Pedro & $1,156,003$ & 354 \\
Vallee de Bandama & Bouake & 730,351 & 315 \\
Woroba & Seguela & 428,399 & 473 \\
Zanzan & Bondoukou & 473,621 & 403 \\
Savanes & Korhogo & 814,836 & 564 \\
Mali & Bamako & 839,092 & 1173 \\
Burkina Faso & Ouagadougou & $1,421,435$ & 1145 \\
Niger & Niamey & 45,105 & 1622 \\
\hline
\end{tabular}

the market area of a rail-road terminal by taking a carrier's point of view and comparing the cost of transportation solutions (Table 3).

The market area is determined by all $\mathrm{M}$ points for which intermodal transport is cheaper than road transport (see Figure 4).

\subsection{Model Application Using Abidjan Port as Case Study}

In this section, the problem of the p-median will be formulated with Lingo Mathematical Language (Appendix 1) in the case of a rail-road network where post-routing is done by road and rail link between terminal.

The problem define above is a linear optimization formulation for minimum cost network flow. In modeling the problem several assumptions and considerations were made, namely:

- There is only one source node (Abidjan port) and five potentials terminal

- The number and location of proposed intermodal terminal are known (exogenous model), hence the model evaluates the optimality of location, number of terminal to be included in the network and optimal for attaining the minimum cost for freight flows through the port.

- The installation and fixed cost of terminals are not considered.

- The capacity (annual throughput) of terminals is unlimited.

- Not direct shipping constraint 


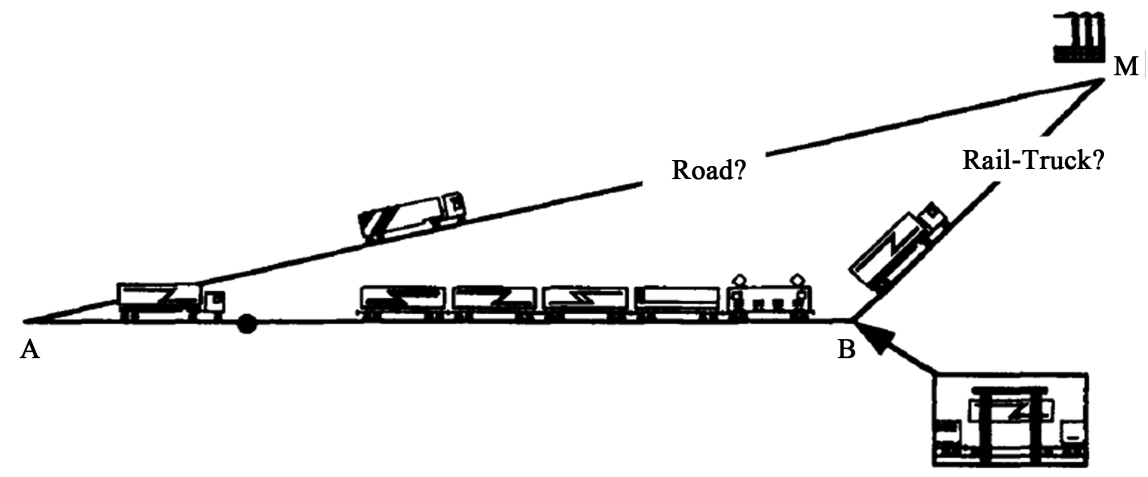

Figure 4. Potential terminal market area. Source: Nierat, 1997.

Table 3. Potential terminal market area.

\begin{tabular}{|c|c|c|c|}
\hline $\begin{array}{l}\text { Terminal } \\
\text { ID }\end{array}$ & $\begin{array}{l}\text { City Name } \\
\text { as Potential }\end{array}$ & Market Area & $\begin{array}{c}\text { Freight } \\
\text { Demanded } \\
\text { Associated } \\
\text { (Ton) }\end{array}$ \\
\hline $\mathrm{Y} 1$ & Abgoville & Abidjan-Gagnoa-Dabou-San Pedro & 5.5183 .59 \\
\hline Y2 & Dimbokro & Yamoussoukro-Dimbokro-Abengourou-Man-Daloa & $3,792,835$ \\
\hline Y3 & Bouake & Bouake-Boudoukou-Seguela & $1,632,371$ \\
\hline Y4 & Katiola & Seguela & 428,399 \\
\hline Y5 & Ferkessedougou & Odienne-Korhogo-Bamako-Ouagadougou-Niamey & $3,267,356$ \\
\hline Y6 & Ouangolodougou & Bamako-Ouagadougou-Niamey & $2,305,632$ \\
\hline
\end{tabular}

\section{Model Results}

The problem is solved for different value of $\mathrm{p}$. The evolution of the total transportation cost according to the number of implanted terminal, ranging from one to six, shows that there is a minimum for a number of terminal equal to three.

When the optimal locations of one (01) intermodal terminal among the six (06) potential locations, the objective function is minimized in the case of a terminal located in Abgoville $\mathrm{Y}_{1}$, (Appendix 2).

When two terminals (02) are determined, the minimization of the objective function is obtained when a terminal Abgoville $\mathrm{Y}_{1}$ and the second at Ferkessedougou $Y_{5}$, (Appendix 3).

When three (03) terminals are determined, the minimization of the objective function is obtained when a terminal Abgoville $Y_{1}$, Bouake $Y_{3}$ and at Ferkessedougou $Y_{5}$, (Appendix 4).

Then three additional configurations, at four, five and six terminals, were studied. The total costs in those configurations are greater than the third configuration result (Appendices 5-7).

When $\mathrm{p}$ varies between one and three (Table 4 ) the total cost decreases as the number of terminals increases $(0.3914773 \mathrm{E}+09$ to $0.3542181 \mathrm{E}+09)$. The total logistic cost cannot be reduced by adding another terminal. 
Table 4. Terminal located summary.

\begin{tabular}{|c|c|c|c|}
\hline $\begin{array}{l}\text { Number } \\
\text { of terminal } \\
\text { to be Located }\end{array}$ & Name of Terminal Located & Terminal ID & Total Logistic Cost \\
\hline$P=1$ & Agboville & $\mathrm{Y}_{1}$ & $0.3914773 \mathrm{E}+09$ \\
\hline $\mathrm{P}=2$ & Agboville and Ferkessedogou & $\mathrm{Y}_{1}-\mathrm{Y}_{5}$ & $0.3910420 \mathrm{E}+09$ \\
\hline $\mathrm{P}=3$ & Abgoville-Bouake and Ferkessedougou- & $\mathrm{Y}_{1}-\mathrm{Y}_{3}-\mathrm{Y}_{5}$ & $0.3542181 \mathrm{E}+09$ \\
\hline $\mathrm{P}=4$ & Abgoville-Bouake-Katioala and Ferkessedougou & $\mathrm{Y}_{1}-\mathrm{Y}_{3}-\mathrm{Y}_{4}-\mathrm{Y}_{5}$ & $0.3988296 \mathrm{E}+09$ \\
\hline$P=5$ & Agboville-Dimbokro-Bouake-Katiola-Ferkessedougou & $Y_{1}-Y_{2}-Y_{3}-Y_{4}-Y_{5}$ & $0.3988296 \mathrm{E}+09$ \\
\hline$P=6$ & Agboville-Dimbokro-Bouake-Katiola-Ferkessedougou-Ouangolodougou & $\mathrm{Y}_{1}-\mathrm{Y}_{2}-\mathrm{Y}_{3}-\mathrm{Y}_{4}-\mathrm{Y}_{5}-\mathrm{Y}_{6}$ & $0.3988296 \mathrm{E}+09$ \\
\hline
\end{tabular}

\section{Conclusions}

This paper focused on providing a methodology for determining the optimal locations for intermodal freight transportation terminals in consolidation network. Our goal is to minimize total costs in order to increase the efficiency of the transportation system.

Among the different types of intermodal transport, our application focuses on the location of container terminals in the framework of combined rail-road transport.

Our research focusses on the design of intermodal transport network in West Africa based on the hinterland of Abidjan port in Cote d'Ivoire. Therefore, a model has been formulated to find optimal locations for rail-road terminals. The results shows that three (03) terminal should to be located.

In this study, only import freight was used in the model and it was considered that the same approach could be used for analysis of export and import flow and other type of cargo. The subject area for optimal evaluation for forward and reserve logistics of the flows is left as an area for further study.

As concept, intermodality involves internalization of transport related externalities. Due to the difficulty in finding data on transport related pollution, the environmental parameters were also not included in our quantitative analysis.

\section{Conflicts of Interest}

The author declares no conflicts of interest regarding the publication of this paper.

\section{References}

[1] Mitsuo, G., Cheng, R.-W. and Lin, L. (2008) Network Models and Optimization, Multi-Objective Genetic Algorithm Approach. Springer-Verlag Ltd., Berlin//Heidelberg, Germany.

[2] Japon International Cooperation Agency (2009) The Research on Cross Border Transport Infrastructure Phase3.

[3] Cullinane, K. and Wilmsmeier G. (2011) The Contribution of the Dry Port Concept to the Extension of Port Life Cycles. In: Böse, J., Ed., Handbook of Terminal Plan- 
ning. Operations Research/Computer Science Interfaces Series, Springer, New York. https://doi.org/10.1007/978-1-4419-8408-1_18

[4] Talley, W.K. (2009) Port Economic. Routledge, London. https://doi.org/10.4324/9780203880067

[5] Roso, V. (2008) Factors Influencing Implementation of a Dry Port. International Journal of Physical Distribution \& Logistic Management, 38, 782-798. https://doi.org/10.1108/09600030810926493

[6] Roso, V., Woxenius, J. and Lumsden, K. (2009) The Dry Port Concept: Connecting Container Seaport with the Hinterland. Journal of Transport Geography, 17, 338345. https://doi.org/10.1016/j.jtrangeo.2008.10.008

[7] Venstra, A., Zuidwijk, R. and van Asperen, E. (2012) The Extended Gate Concept for Container Terminals: Expanding the Notion of Dry Ports. Maritime Economics \& Logistics, 14, 14-32. https://doi.org/10.1057/mel.2011.15

[8] Wilmsmeier, G., Moniosa, J. and Lambert, B. (2011) The Directional Development of Intermodal Freight Corridors in Relation to Inland Terminals. Journal of Transport Geography, 19, 1379-1386. https://doi.org/10.1016/j.jtrangeo.2011.07.010

[9] Hanaoka, S. and Regmi, M.B. (2011) Promoting Intermodal Freight Transport through and Development of Dry Port in Asia: An Environmental Prospective. IATSS Research, 35, 16-23. https://doi.org/10.1016/j.iatssr.2011.06.001

[10] Ng, A.K.Y and Gujar, G.C. (2009) The Special Characteristics of Inland Transport Hub: Evidence from Southern India. Journal of Transport Geography, 17, 346-356. https://doi.org/10.1016/j.jtrangeo.2008.07.010

[11] Ng, A.K.Y. and Tongzon, J.L. (2010) The Transport Sector of India's Economy: Dry Ports as Catalysts for Region Development. Eurosian Geography and Economics, 5, 669-682. https://doi.org/10.2747/1539-7216.51.5.669

[12] Dadvar, E, Ganji, S.R.S. and Tanzifi, M. (2011) Feasibility of Establishment of Dry Port in Developing Countries-The Case of Iran. Journal of Transport Security, 4, 19-33. https://doi.org/10.1007/s12198-010-0056-x

[13] Padiha, F. and Ng, A.K.Y. (2012) The Evolution of Dry Port in Developing Economies: The Brazilian Experience. Maritime Economics \& Logistic, 14, 99-121. https://doi.org/10.1057/mel.2011.18

[14] Arnold, P. (2002) Localisations optimales, logique multi-réseaux et terminaux de transport multimodal: formalisation et applications, Thèse, Département de Géologie et de Géographie, Université catholique de Louvain.

[15] Mao, S. and Demetsky, M.J. (2002) Calibration of the Gravity Model for Truck Freight Flow Distribution (No. UVACTS-5-14-14,). University of Virginia.

[16] Hotelling, H. (1929) Stability in Competition. The Economic Journal, 39, 41-57. https://doi.org/10.2307/2224214

[17] Berry, B.J.L. (1967) Geography of Market Centers and Retail Distribution. Prentice Hall Inc., Englewood Cliffs, NJ.

[18] Niérat, P. (1997) Market Area of Rail-Truck Terminals: Pertinence of the Spatial Theory. Transportation Research Part A: Policy and Practice, 31, 109-127. https://doi.org/10.1016/S0965-8564(96)00015-8 


\section{Appendix 1: Lingo Model for Terminal Location}

SETS:

TERMINAL/1..6/:Y;

ORIGIN/1/;

DESTINATION/1..17/:A;

MODE/1,2/;

LINKS1 (ORIGIN, TERMINAL, MODE):X1;

LINKS2 (TERMINAL, DESTINATION, MODE):X2;

LINKS3(ORIGIN,TERMINAL):D1;

LINKS4(TERMINAL,DESTINATION):D2;

ENDSETS

THE OBJECTIVE FUNCTION;

MIN=TOTALCOST;

@SUM(ORIGIN(O):@SUM(TERMINAL(i):@SUM(MODE(R):D1(O,I)*

$\mathrm{X}(\mathrm{O}, \mathrm{I}, \mathrm{R}))))+$

@SUM(TERMINAL(i):@SUM(DESTINATION(j):@SUM(MODE(R):D2(i,j)*

$\mathrm{X} 2(\mathrm{I}, \mathrm{J}, \mathrm{R})))$ );

CONSTRAINTS;

@FOR(ORIGIN(O):@FOR(TERMINAL(i):@FOR(MODE(r):xl(O,I,R) $<=\mathrm{M}^{\star} \mathrm{Y}$

$(\mathrm{I})))$ );

@FOR(TERMINAL(i):@FOR(DESTINATION(J):@FOR(MODE(R):X2(I,J,R)

$\left.\left.\left.<=\mathrm{M}^{\star} \mathrm{Y}(\mathrm{I})\right)\right)\right)$;

@SUM(TERMINAL(I):Y(I))=P;

@FOR(DSTINATION(j):@SUM(MODE(R):@SUM(TERMINAL(I):x2(I,J,R)))

$=\mathrm{A}(\mathrm{J}))$;

@FOR(TERMINAL(I):@FOR(DESTINATION(j):@FOR(MODE(R):X2(I,J,R)

$>=0))$ );

@FOR(ORIGIN(O):@FOR(TERMINAL(I):@FOR(MODE(R):x1(O,I,R)>=0)))

;

@FOR(TERMINAL(I):Y(I)>=0);

@FOR(TERMINAL(I):@BIN(Y(I)));

DATA

Appendix 2: Lingo Results for Determining One (01)

Terminal

Global optimal solution found.

Objective value: $0.3914773 \mathrm{E}+09$

Objective bound: $0.3914773 \mathrm{E}+09$

Infeasibilities: 0.000000

Extended solver steps: 0

Total solver iterations: 16

Variable Value Reduced Cost

$\begin{array}{lll}\mathrm{Y}(1) & 1.000000 & 0.000000\end{array}$ 


\section{Appendix 3: Lingo Results for Determining Two (02)} Terminals

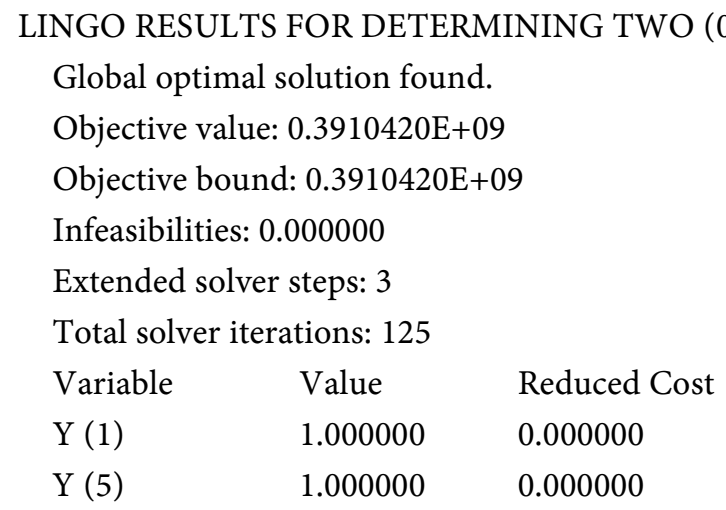

Appendix 4: Lingo Results for Determining Three (03) Terminals

LINGO RESULTS FOR DETERMINING TREE (03) TERMINALS

Global optimal solution found.

Objective value: $0.3542181 \mathrm{E}+09$

Objective bound: $0.3542181 \mathrm{E}+09$

Infeasibilities: 0.000000

Extended solver steps: 3

Total solver iterations: 93

Variable Value Reduced Cost

$\mathrm{Y}(1) \quad 1.000000 \quad 0.000000$

$\mathrm{Y}(2) \quad 1.000000 \quad 0.000000$

$\mathrm{Y}(4) \quad 1.000000 \quad 0.000000$

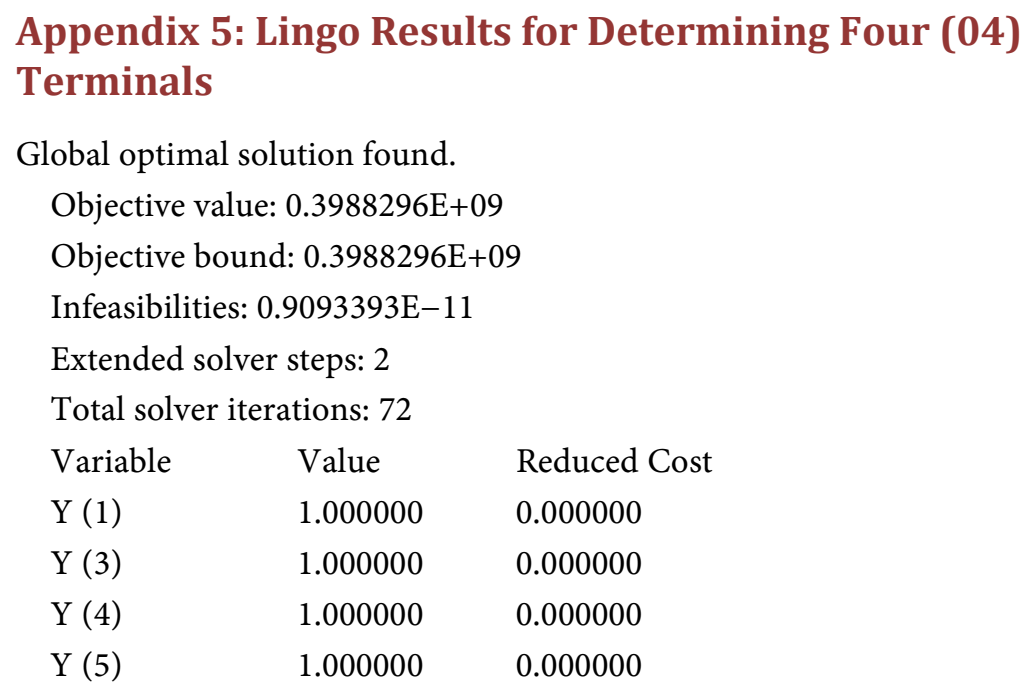

\section{Appendix 6: Lingo Results for Determining Five (05)} Terminals

Global optimal solution found. 
Objective value: $0.3988296 \mathrm{E}+09$

Objective bound: $0.2868296 \mathrm{E}+09$

Infeasibilities: 0.000000

Extended solver steps: 0

Total solver iterations: 51

Variable Value

Y (1) 1.000000

Reduced Cost

$\mathrm{Y}(1)$

1.000000

0.000000

$\mathrm{Y}(2)$

1.000000

0.000000

$\mathrm{Y}(3)$

1.000000

0.000000

$\mathrm{Y}(4)$

1.000000

0.000000

Y (5)

1.000000

0.000000

\section{Appendix 7: Lingo Results for Determining Six (06) Terminals}

Global optimal solution found.

Objective value: $0.3988296 \mathrm{E}+09$

Objective bound: $0.2868296 \mathrm{E}+09$

Infeasibilities: 0.000000

Extended solver steps: 0

Total solver iterations: 0

$\begin{array}{lll}\text { Variable } & \text { Value } & \text { Reduced Cost } \\ \text { Y (1) } & 1.000000 & 0.000000 \\ \text { Y (2) } & 1.000000 & 0.000000 \\ \text { Y (3) } & 1.000000 & 0.000000 \\ \text { Y (4) } & 1.000000 & 0.000000 \\ \text { Y (5) } & 1.000000 & 0.000000 \\ \text { Y (6) } & 1.000000 & 0.000000\end{array}$

